NASA Contractor Report 195364

AIAA-94-3309

\title{
Status of Hollow Cathode Heater Development for the Space Station Plasma Contactor
}

George C. Soulas

NYMA, Inc.

Engineering Services Division

Brook Park, Ohio

July 1994

Prepared for

Lewis Research Center

Under Contract NAS3-25266

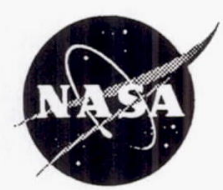

National Aeronautics and

Space Administration 


\title{
Status of Hollow Cathode Heater Development for the Space Station Plasma Contactor
}

\author{
George C. Soulas \\ NYMA, Inc. \\ NASA Lewis Research Center Group \\ Brook Park, Ohio
}

\begin{abstract}
A hollow cathode-based plasma contactor has been selected for use on the Space Station. During the operation of the plasma contactor, the hollow cathode heater will endure approximately 12000 thermal cycles. Since a hollow cathode heater failure would result in a plasma contactor failure, a hollow cathode heater development program was established to produce a reliable heater. The development program includes the heater design, process documents for both heater fabrication and assembly, and heater testing. The heater design was a modification of a sheathed ion thruster cathode heater. Heater tests included testing of the heater unit alone and plasma contactor and ion thruster testing. To date, eight heaters have been or are being processed through heater unit testing, two through plasma contactor testing, and three through ion thruster testing, all using direct current power supplies. Comparisons of data from heater unit performance tests before cyclic testing, plasma contactor tests, and ion thruster tests at the ignition input current level show the average deviation of input power and tube temperature near the cathode tip to be $\pm 0.9 \mathrm{~W}$ and $\pm 21^{\circ} \mathrm{C}$, respectively. Heater unit testing included cyclic testing to evaluate reliability under thermal cycling. The first heater, although damaged during assembly, completed 5985 ignition cycles before failing. Four additional heaters successfully completed $6300,6300,700$, and 700 cycles. Heater unit testing is currently ongoing for three heaters which have to date accumulated $>7250,>5500$, and $>5500$ cycles.
\end{abstract}

\section{Introduction}

A hollow cathode-based plasma contactor has been baselined for use on Space Station to reduce station charging. ${ }^{1}$ The hollow cathode utilized by the plasma contactor requires a heater to provide heat to remove contaminants from the cathode electron emitting insert surface during activation and to ignite the discharge. ${ }^{1}$ Although it is not anticipated that the plasma contactor will be cycled on and off, the contactor emission current to the space plasma will vary throughout the course of an orbit ${ }^{1}$ which will impart a cyclic thermal load onto the heater. It is anticipated that the heater will endure approximately 12000 thermal cycles, most of which will occur to an unpowered heater. Without a reliable heater that can withstand these thermal cycles, the plasma contactor may fail.

Ion thrusters also utilize heaters for the discharge and neutralizer hollow cathodes. The $30-\mathrm{cm}$ xenon ion thruster ${ }^{2}$ utilizes the same heater as that of the plasma contactor. Near term applications for ion thruster technology include north-south station-keeping and on-

This paper is a declared work of the U.S. Government and is not subject to copyright protection in the United States. orbit repositioning missions. ${ }^{3-7}$ For these missions, it is anticipated that the thruster cathodes will be operated for 3000-4000 on-off cycles on large communication and earth sensing satellites to achieve lifetimes in excess of ten years. ${ }^{3-7}$ A reliable heater will be essential to meet these life time requirements.

Potted heaters, alumina flame/plasma sprayed heaters, and sheathed heaters have been developed for plasma contactors and ion thrusters. Although all heater types have been successfully tested, ${ }^{8-11}$ only alumina flame/plasma sprayed and sheathed hollow cathode heaters were investigated in this program since there was a considerable amount of experience with these types at the NASA Lewis Research Center (LeRC). While alumina flame/plasma sprayed hollow cathode heaters were successfully flight tested on the SERT II spacecraft, ${ }^{10}$ a later program, using larger diameter cathodes, revealed that the alumina insulation was prone to cracking after fewer than 1000 thermal cycles, and that this cracking typically resulted in a heater failure. ${ }^{11}$ Furthermore, fabrication procedures for alumina flame/plasma sprayed heaters involved high levels of skill and attention to detail that exceeded those required for sheathed heaters. ${ }^{12}$ To avoid these problems, sheathed heaters were utilized. Sheathed heaters 
were shown to operate reliably for thousands of on-off cycles for both ion thrusters ${ }^{11}$ and resistojets, ${ }^{13}$ and were baselined for use on the $\mathrm{J}$-series $30-\mathrm{cm}$ mercury ion thruster, an engineering model thruster for a solar electric propulsion system ground demonstration program. ${ }^{14}$ The J-series hollow cathode heater design, however, suffered from a high failure rate during acceptance testing and a termination design that was complex, fragile, and difficult to fabricate. ${ }^{14}$

For the plasma contactor hollow cathode heater, the J-series hollow cathode heater design was modified to increase heater reliability. A test program was developed to verify relliability under thousands of cyclic thermal loads. ${ }^{15}$ The test program included the development of heater design, fabrication, and inspection procedures; the assembly of a heater test facility with a computer data acquisition and control system; and heater testing to determine power requirements and to evaluate operational repeatability and reliability. Heater testing is currently ongoing and several heaters have completed testing.

This paper presents the status of the heater development program for the Space Station plasma contactor. The heater development program is initially reviewed. Aspects of the experimental program, including the test facility, the heater design, and the heater test procedures, are then reviewed. Finally, results from heater testing are presented and discussed.

\section{Heater Development Program}

A flow chart describing the hollow cathode heater development program is shown in Fig. 1. The heater development program was designed to be an iterative process between the heater design and process documents, the heater assembly, and heater testing. The heater design and process documents were based on heater requirements for the plasma contactor cathode. Following heater assembly, the heaters were tested, and results from these tests were used to modify the heater design and process documents. The hollow cathode heater design is validated upon successful completion of all heater testing.

The heater design was a sheathed concept and is shown in Fig. 2. The basic elements of the heater are the center conductor, the insulator, the sheath, the terminations, and the radiation shield. The center conductor is the heat source, the sheath encloses the heating element and closes the electrical circuit, and the insulator provides for electrical isolation and thermal conduction between the center conductor and sheath.
The terminations couple the center conductor to the circuit, and the radiation shield reduces radiated power losses. The detailed heater design will be discussed in a later section.

The fabrication procedures were written with sufficient detail to ensure repeatability of the assembly process. They include specifications for all cleaning, swaging, annealing, welding, and brazing processes, as well as assembly procedures. Inspection procedures were included to ensure successful heater fabrication. These procedures include visual, radiographic, and thermographic inspections, an insulation compaction measurement, and cold resistance measurements. The heater assembly process includes a record of all material data to ensure traceability of heater components, as well as the implementation of fabrication and inspection procedures.

An acceptance testing procedure is conducted before all tests as a final check of heater unit reliability. This test includes cold heater resistance measurements before and after completing a series of on-off cycles. Heater tests for design validation include testing of the heater unit alone, plasma contactor and ion thruster testing, and vibrational testing of plasma contactor. Ion thruster data are included because the $30-\mathrm{cm}$ xenon ion thruster tested at LeRC utilizes the same heater design since operational and testing requirements are similar to those of the plasma contactor. $^{2} \quad$ This paper will focus on heater unit, plasma contactor, and ion thruster tests. Heater unit testing includes performance testing and cyclic testing. Performance testing is used to determine power requirements, single unit operational repeatability, and unit-to-unit operational repeatability. Performance tests are conducted before and after cyclic testing. Cyclic testing is used to evaluate heater reliability under a cyclic thermal load by subjecting the heater to an ion thruster qualification test appropriate for a ten year, north-south station-keeping mission on a large communication satellite. Results from plasma contactor and ion thruster testing include results from cathode activation, heater acceptance testing, and cyclic testing.

\section{Test Apparatus}

\section{Heater Test Facility and Apparatus}

All heater unit testing, which included performance and cyclic testing, was conducted within a $0.31 \mathrm{~m}$ inner diameter, $0.36 \mathrm{~m}$ long stainless steel port that was mounted onto a larger vacuum facility. A photograph of the test facility is shown in Fig. 3. The port was 
isolated from the vacuum facility and was pumped by a turbo-molecular pump that was backed by a mechanical pump. Base port pressures were on the order of $1.3 \times 10^{-4} \mathrm{~Pa}$ as measured by an ionization gauge. A low background pressure was necessary to preclude excessive oxidation of heater and cathode components which could result in inaccurate performance data and/or failure. This range was satisfactory as past tests of sheathed heaters were successfully conducted within this pressure range. ${ }^{11}$

The heaters were mounted onto hollow cathodes with electron emitting inserts installed to simulate the cathode thermal mass. The cathodes were secured to ceramic isolators that were mounted on a steel platform with stainless steel sheet metal for radiation shields, as shown in Fig. 4. This arrangement was designed to accommodate the testing of three heaters simultaneously. No attempt was made to initiate a discharge.

A schematic of the computerized data acquisition and control (DAC) system utilized for heater testing is shown in Fig. 5. A computer and a digital-to-analog converter were used with a General Purpose Interface Bus (GPIB) to control three $16 \mathrm{~V}, 10 \mathrm{~A} \mathrm{DC}$ heater power supplies. Use of direct current for the hollow cathode heater allowed for reduced conducted and radiated electromagnetic interference during plasma contactor activation and ignition. With the heater as a load, the current regulation and ripple of the power supplies were $<0.8 \%$ and $<0.81 \%$, respectively. The computer-GPIB configuration was further used to control a 16 channel multiplexer and an analog-todigital converter for data acquisition. The multiplexer, which contained signal conditioners to electrically isolate the DAC system and to condition incoming signals, was commanded to send its analog signals to an analog-to-digital converter which then was commanded to send the converted digitized signals to the computer via the GPIB. The computer saved these data on an external disk drive and printed a hard copy. Monitored parameters included heater currents and voltages, tube temperatures near the cathode tip, and port pressure. Currents were measured with current transducers, voltages with volt meters, temperatures with platinum/platinum-13\% rhodium thermocouples, and port pressures with an ionization gauge. The estimated accuracies of these measurements are listed in Table 1. A strip chart recorder was installed to continuously monitor the heater currents, voltages, and the port pressure.

\section{Heater Design}

The modified heater design is shown in Fig. 2. It is a modified version of the J-series ion thruster heater design. It consists of a sheathed heater with eight helical coils used to heat the hollow cathode. The amount of swaging was reduced to avoid damaging the center conductor and the insulation thickness was increased to preclude the center conductor from making contact with the sheath during the swaging process. The reduced swaging resulted in a larger center conductor diameter than the J-series cathode heater. The heater impedance at ignition temperature was approximately $1.1 \Omega$ Although this low impedance imposes a loss in power processor efficiency due to the low operating voltages, heater reliability is increased due to the decreased probability of damaging the center conductor during the swaging process. For the heater termination, the center conductor of the sheathed heater was welded to a larger diameter wire. A sleeve was brazed to the sheathed heater and filled with a high temperature ceramic cement. This assembly removes stress from the center conductor and reduces resistive power losses. The wire was terminated with a stakeon. The radiation shield was a metal foil shield that was wrapped around the heater coils and was retained by spot-welds.

\section{Heater Test Procedures}

Heater unit testing consisted of performance and cyclic testing. Performance testing involved ramping the heater input current to a fixed current level in order to measure the tube temperature near the cathode tip as a function of input power. This test was conducted before and after cyclic testing. The heater produced a maximum tube temperature of $\sim 1100^{\circ} \mathrm{C}$. Cyclic testing involved cycling the heater to ignition temperatures for 6000 cycles, although this number was decreased to 700 cycles for some heaters in order to process more heaters so that unit-to-unit repeatability could be assessed. Each cycle consisted of 10 minutes at high heat input power to simulate ignition and 10 minutes at power off for cooling. A typical temperature characteristic is shown in Fig. 6. The ignition time and input power simulation were maximum values chosen pending testing to determine an actual ignition time and input power. The cooling time was chosen to impose a significant thermal stress on the heater while minimizing cycle time. The rate of heater cooling was found to decrease substantially within the first 10 minutes of heater power shut-down. Acceptance testing results were included in the cyclic test data.

Heater data from plasma contactor and ion thruster testing included results from cathode activations and heater acceptance tests. Acceptance test data were 
gathered using a lower input power than those of heater unit testing since a recent study showed the necessary ignition power to be less than the maximum conditions for heater unit testing described above. ${ }^{16}$

\section{Results and Discussion}

\section{Status of Testing}

To date, eight heaters have been or are being processed through heater unit testing, two through plasma contactor testing, and three through ion thruster testing. The status of the eight heaters processed through heater unit testing is listed in Table 2. Heater PCU-H-001 was assembled without any inspection of the hardware during fabrication. The testing objectives of this heater were to verify that the heater termination design was satisfactory and to obtain an initial estimate on the cyclic lifetime capability of the design. Furthermore, during the installation of the heater onto the hollow cathode, the heater sheath surface and shape were damaged. Testing was conducted, however, since no heater insulation was exposed and the heater cold resistance did not change. The remaining heaters were fabricated and inspected according to the process documents. The installation procedure of the heater onto the cathode was modified to prevent damaging the heaters. Heater PCU-H-004 was used for a plasma contactor model. Pre-cyclic performance data have been obtained for all heaters. Post-cyclic performance measurements were not made on heater PCU-H-001 due to a failure during cyclic testing and heaters PCU$\mathrm{H}-005,-008$, and -009 because cyclic testing of these heaters is still in progress. The latter heaters have completed their planned 6000 or 700 cycles, however their testing was extended due to the delayed fabrication of additional heaters planned for heater unit testing.

The status of heaters processed through plasma contactor and ion thruster testing is listed in Table 3. All heater hardware successfully completed acceptance testing. Plasma contactor HCA-002 was used in the evaluation of contactor ignition characteristics ${ }^{16}$ and is currently being cycled for ignition reliability evaluations. Plasma contactor HCA-006 is currently being lifetested. Ion thruster neutralizer NEUT-1 was damaged during thruster performance testing and was replaced by NEUT $-2{ }^{2}$ The ion thruster will be lifetested to 2000 hours. $^{2}$ Data from these heaters have been used to further assess unit-to-unit repeatability and heater acceptance testing procedures. Ion thruster neutralizer heater data, however, were not included due to excessive noise in the voltage signal.

\section{Cyclic Testing}

Cyclic testing results for all heaters are shown in Fig. 7 where the peak input powers per cycle are shown throughout cyclic testing. These results show a number of trends. Initially, the heater input power increased sharply within the first 150 cycles. This occurrence, defined as heater "burn-in", will be explained later. After "burn-in", the input power either remained constant for $700-2000$ cycles or started gradually increasing at rates about $1 \times 10^{-3}$ to $2 \times 10^{-3}$ $\mathrm{W} /$ cycle. Those heaters that exhibited gradual increases continued to do so until the test's end and those that remained constant for $700-2000$ cycles then started increasing at approximately the same rate. The input powers of heaters PCU-H-001, -002 , and -003 , increased by $6.4 \%, 13.6 \%$, and $17.0 \%$ of their starting values while those of PCU-H-005, -008 , and -009 have increased by $10.8 \%, 8.3 \%$, and $4.8 \%$, respectively. The increase in power throughout cyclic testing was caused by an increase in center conductor resistance. The post-test cold resistances of heaters PCU-H-002 and -003 were found to have increased by approximately $0.1 \Omega$ This cold resistance increase would largely account for the hot resistance increase by the end of the test, which was found to be approximately $0.1-0.2 \Omega$ for both heaters. The cause of the resistance increase is currently being investigated. The increases of the peak cycle input power do not adversely affect the heater's function because the plasma contactor power processor can provide the additional power necessary to operate the heater. ${ }^{17}$

The only heater to fail cyclic testing was heater PCU-H-001 which failed after completing 5985 cycles of a planned 6000 cycles. The failure occurred several seconds into cycle 5986, when the heater abruptly went open circuit. This failure was later found to be a fracture in the center conductor at the fourth coil from the heliarc welded termination. An examination revealed that the fracture was caused by the center conductor "necking" down at this location. This "necking" is further demonstrated by the sharp increase in the peak cycle input power from cycle 5941 at 66.0 $\mathrm{W}$ to cycle 5985 at $66.6 \mathrm{~W}$. The cause of the "necking" may have been a combination of two effects: 1) microfractures in the center conductor caused by an improper installation of the heater onto the cathode and 2) a reduction of the tantalum center conductor diameter due to reactions with impurities in the magnesium oxide. The evidence for the microfractures is the higher operating power levels of this heater compared 
to other heaters tested to date. Impurities in the magnesium oxide likely aggravated this problem further until a failure occurred. Later heaters (PCU-H-002 and beyond) utilized strict fabrication and installation procedures that precluded this failure.

Unit-To-Unit and Single Unit Repeatability Testing

Pre-cyclic performance testing results were used for evaluating unit-to-unit repeatability. Heater power and tube temperature near the cathode tip as a function of the input current are shown in Figs. 8 and 9. Input power and cathode temperature and dispersions for all heaters increased with input current to maximums of $4.4 \mathrm{~W}$ and $85^{\circ} \mathrm{C}$, respectively. Table 4 shows input powers and cathode temperatures resulting from the ignition current. Plasma contactor and ion thruster test results were also included. The mean input powers and cathode temperatures were $54.4 \mathrm{~W}$ and $1051{ }^{\circ} \mathrm{C}$, respectively, with average deviations of $\pm 0.9 \mathrm{~W}$ and $\pm 21^{\circ} \mathrm{C}$, respectively. The average deviation in power was within the accuracy of the power measurement, which was $\pm 1.2 \mathrm{~W}$ at this mean input power level. The average deviation of input power required to achieve a fixed temperature was equivalent to that of past ion thruster heater testing. ${ }^{11}$ This indicates excellent unit-to-unit repeatability in input power. The average deviation in cathode temperature was larger than the estimated accuracy of the measurement. This was probably due, in part, to the difficulty in assuring adequate simulation of thermocouple location and thermal interface characteristics from heater to heater. ${ }^{15}$

Comparisons of pre- and post-cyclic performance testing results were used to evaluate single unit repeatability with time. Typical heater power and tube temperature near the cathode tip as a function of the input current are shown in Figs. 10 and 11, respectively, for heater PCU-H-003. Comparisons of pre-and post-cyclic performance results are shown in Table 5 for a fixed input current of 7.2 A. The general trend was that input power and cathode temperature increased with time except for heaters -006 and -007 , which were only tested for 700 cycles. The maximum increase in input power, which was $13.3 \%$ of the starting value, was used in part to determine the maximum power limit for the heater power processor. ${ }^{17}$

\section{"Burn-In" Analysis}

The initial cycles of cyclic testing where the peak cycle input power increases sharply with each cycle were defined as "burn-in" cycles. Table 6 lists the number of "burn-in" cycles and the associated input power and temperature increases for all heaters tested to date. Except for heater PCU-H-006, the powers and temperatures for each heater increased during the "burn-in" period, indicating that the center conductor resistance increased since more power was dissipated at the cathode. Causes of the increases are presently unknown.

The average number of "burn-in" cycles, excluding heater PCU-H-006, was 60 and the maximum number of cycles was 140. During acceptance testing, it is necessary to ensure that the peak cycle input power had stopped increasing sharply after a heater "burn-in" had occurred. These results were therefore utilized to modify the acceptance test cycling procedure.

\section{Conclusion}

The status of the hollow cathode heater development program was discussed. The development program, which includes the heater design, process documents for both heater fabrication and assembly, and heater testing, was established to validate the plasma contactor heater design. Ion thruster data were included because the $30-\mathrm{cm}$ xenon ion thruster tested at LeRC utilizes the same heater design since operational and testing requirements are similar to those of the plasma contactor. To date, eight heaters have been or are being processed through heater unit testing, two through plasma contactor testing, and three through ion thruster testing, all using direct current power supplies. Comparisons of data from heater unit performance tests, plasma contactor tests, and ion thruster tests at the ignition input current level show the average deviation of input power and tube temperature near the cathode tip to be $\pm 0.9 \mathrm{~W}$ and $\pm 21{ }^{\circ} \mathrm{C}$, respectively. Heater unit testing included cyclic testing to evaluate reliability under thermal cycling. The first heater, although damaged during assembly, completed 5985 ignition cycles before failing. Four additional heaters have completed $6300,6300,700$, and 700 cycles of a planned $6000,6000,700$, and 700 cycles, respectively. Heater unit testing is currently ongoing for three heaters which have accumulated $>7250,>5500$, and $>5500$ cycles to date. Results from the heater "burnin" analysis were used to modify acceptance testing procedures.

\section{References}

${ }^{1}$ Patterson, M. J., Hamley, J. A., Sarmiento, C. J., Manzella, D. H., Sarver-Verhey, T., Soulas, G. C., 
and Nelson, A., "Plasma Contactor Development for Space Station," International Electric Propulsion Conference Paper 93-246, September 1993.

${ }^{2}$ Patterson, M. J., Haag, T., and Rawlin, V., "NASA $30 \mathrm{~cm}$ Ion Thruster Development Status," AIAA Paper 94-2849, June 1994.

${ }^{3}$ Pollard, J. E., Jackson, D. E., Marvin, D. C., Jenkin, A. B., and Janson, S. W., "Electric Propulsion Flight Experience and Technology Readiness," AIAA Paper 93-2221, June 1993.

${ }^{4}$ Schreib, R., "Readiness Appraisal: Ion Propulsion for Communication Satellites," AIAA Paper 88-0777, May 1988.

${ }^{5}$ Rawlin, V. K. and Majcher, G. A., "Mass Comparisons of Electric Propulsion Systems for NSSK of Geosynchronous Spacecraft, " AIAA Paper 91-2347, June 1991.

${ }^{6}$ Beattie, J. R., Matossian, J. N., and Robson, R. R., "Status of Xenon Ion Propulsion Technology," AIAA Paper 87-1003, May 1987.

${ }^{7}$ Kitamura, S., Miyazaki, K., and Hayakawa, Y., "Cyclic Test of a $14 \mathrm{~cm}$ Diameter Ring-Cusp Xenon Ion Thruster," AIAA Paper 92-3146, July 1992.

${ }^{8}$ Rohden, H. V., Cirri, G. F., and Matticari, G., "Endurance Test of PROEL Neutralizer for the RIT 10: Review of the Activities at ESTEC Laboratories," International Electric Propulsion Conference Paper 91026, October 1991.

${ }^{9}$ Shimada, S., Satoh, K., Gotoh, Y., Nishida, E., Noro, T., Takegahara, H., Nakamaru, K., and Nagano, H., "Ion Thruster Endurance Test Using Development Model Thruster for ETS-VI, " International Electric Propulsion Conference Paper 93-169, September 1993.

${ }^{10}$ Kerslake, W. R. and Ignaczak, L. R., "Development and Flight History of SERT II Spacecraft," Journal of Spacecraft and Rockets, Vol. 30, No. 3, May-June 1993, pp. 258-290.

${ }^{11}$ Mueller, L. A., "High Reliability Cathode Heaters for Ion Thrusters," AIAA Paper 76-1071, November 1976.

${ }^{12}$ Beattie, J. R. and Matossian, J. N., "Mercury Ion Thruster Technology," NASA CR-174974, March 1989.

${ }^{13}$ Slutz, R. J., "A 10,000-hr Life Test of an Engineering Model Resistojet," NASA TM-103216, October 1990.

${ }^{14}$ Poeschel, R. L. and Dulgeroff, C. R., "Retrofit and Verification Test of $30 \mathrm{~cm}$ Ion Thruster," NASA Contractor Report No. 165233, January 1980.

${ }^{15}$ Soulas, G. C., "Hollow Cathode Heater Develop- ment for the Space Station Plasma Contactor, " NASA CR-191131, October 1993.

${ }^{16}$ Sarver-Verhey, T. R., "Ignition Behavior of the Space Station Plasma Contactor," AIAA Paper 943311, June 1994.

${ }^{17}$ Hamley, J., "Integration Testing of the Space Station Plasma Contactor PEU, " AIAA Paper 94-3307, June 1994. 
Table 1 Estimated Accuracy of Parameter Measurements

\begin{tabular}{cc}
\hline \hline Parameter & Accuracy \\
\hline Input Current, $\mathrm{A}$ & $\pm 1.7 \%$ of reading \\
Input Voltage, $\mathrm{V}$ & $\pm 0.4 \%$ of reading \\
Cathode & $\pm 3{ }^{\circ} \mathrm{C}$ \\
Temperature,${ }^{\circ} \mathrm{C}$ & $\pm 25 \%$ of reading \\
Pressure, $\mathrm{Pa}$ &
\end{tabular}

Table 2 Status of Heater Unit Testing

\begin{tabular}{ccccc}
\hline \hline \multirow{2}{*}{$\begin{array}{c}\text { Heater } \\
\text { Number }\end{array}$} & $\begin{array}{c}\text { Status } \\
\text { Performance }\end{array}$ & Cyclic & $\begin{array}{c}\text { Post-Cyclic } \\
\text { Performance }\end{array}$ & Test Result \\
\cline { 2 - 5 } PCU-H-001 & $\checkmark$ & $5985 / 6000$ & $\mathrm{x}$ & Failure via Center Conductor Fracture \\
-002 & $\checkmark$ & $6300 / 6000$ & $\checkmark$ & Successful Completion \\
-003 & $\checkmark$ & $6300 / 6000$ & $\checkmark$ & Successful Completion \\
-005 & $\checkmark$ & $>7250 / 6000$ & & Testing In Progress \\
-006 & $\checkmark$ & $700 / 700$ & $\checkmark$ & Successful Completion \\
-007 & $\checkmark$ & $700 / 700$ & $\checkmark$ & Successful Completion \\
-008 & $\checkmark$ & $>5500 / 700$ & & Testing In Progress \\
-009 & $\checkmark$ & $>5500 / 700$ & & Testing In Progress \\
\hline $\begin{array}{l}\text { "Cycles Completed/Planned Number of Cycles } \\
\checkmark=\text { Completed } \\
\mathrm{x}=\text { Could Not Be Completed }\end{array}$ & & &
\end{tabular}

Table 3 Plasma Contactor and Ion Thruster Test Status

\begin{tabular}{|c|c|c|c|c|}
\hline \multirow[b]{2}{*}{ Device } & \multirow[b]{2}{*}{ Label } & \multicolumn{3}{|c|}{ Status } \\
\hline & & $\begin{array}{l}\text { Device Test } \\
\text { Type }\end{array}$ & $\begin{array}{c}\text { Heater } \\
\text { Acceptance Test }\end{array}$ & Comments \\
\hline Plasma Contactor & HCA-002 & Cyclic Test & $\checkmark$ & $>500$ Cycles To Date \\
\hline Plasma Contactor & HCA-006 & Life Test & $\checkmark$ & Testing In Progress \\
\hline $\begin{array}{c}\text { Ion Thruster } \\
\text { Discharge Cathode }\end{array}$ & CAT-1 & Life Test & $\checkmark$ & Testing In Progress \\
\hline $\begin{array}{l}\text { Ion Thruster } \\
\text { Neutralizer }\end{array}$ & NEUT-1 & Life Test & $\alpha$ & Replaced with NEUT-2 \\
\hline $\begin{array}{l}\text { Ion Thruster } \\
\text { Neutralizer }\end{array}$ & NEUT-2 & Life Test & $\checkmark$ & Testing In Progress \\
\hline
\end{tabular}


Table 4 Input Power and Temperature at Ignition Current

\begin{tabular}{|c|c|c|c|}
\hline $\begin{array}{l}\text { Device } \\
\text { Tested }\end{array}$ & Label & $\begin{array}{c}\text { Input Power, } \\
\text { W }\end{array}$ & $\begin{array}{c}\text { Cathode } \\
\text { Temperature, }{ }^{\circ} \mathrm{C}\end{array}$ \\
\hline Heater & PCU-H-001 & 57.0 & 1073 \\
\hline$"$ & -002 & 53.1 & 1055 \\
\hline$"$ & -003 & 53.9 & 1034 \\
\hline$"$ & -005 & 55.1 & 1048 \\
\hline$"$ & -006 & 54.1 & 1091 \\
\hline$"$ & -007 & 55.0 & 1068 \\
\hline$"$ & -008 & 53.8 & 1014 \\
\hline$"$ & -009 & 52.8 & 1027 \\
\hline $\begin{array}{c}\text { Plasma } \\
\text { Contactor }\end{array}$ & HCA-002 & 54.2 & - \\
\hline$"$ & -006 & 54.0 & - \\
\hline $\begin{array}{c}\text { Ion Thruste } \\
\text { Discharge } \\
\text { Cathode }\end{array}$ & CAT-1 & 55.2 & - \\
\hline \multicolumn{2}{|c|}{ Mean } & 54.4 & 1051 \\
\hline \multicolumn{2}{|c|}{$\begin{array}{l}\text { Average } \\
\text { Deviation }\end{array}$} & \pm 0.9 & \pm 21 \\
\hline
\end{tabular}

Table 5 Pre-and Post-Cycle Performance at Ignition Current

\begin{tabular}{ccccccc}
\hline \hline & \multicolumn{2}{c}{ Pre-Cyclic } & \multicolumn{2}{c}{ Post-Cyclic } & \multicolumn{2}{c}{ Change } \\
\cline { 2 - 7 } $\begin{array}{c}\text { Heater } \\
\text { Number }\end{array}$ & $\begin{array}{c}\text { Input } \\
\text { Power, } \\
\text { W }\end{array}$ & $\begin{array}{c}\text { Cathode } \\
\text { Temperature } \\
{ }^{\circ} \mathrm{C}\end{array}$ & $\begin{array}{c}\text { Input } \\
\text { Power, } \\
\text { W }\end{array}$ & $\begin{array}{c}\text { Cathode } \\
\text { Temperature, } \\
{ }^{\circ} \mathrm{C}\end{array}$ & $\begin{array}{c}\text { Input } \\
\text { Power, } \\
\text { W }\end{array}$ & $\begin{array}{c}\text { Cathode } \\
\text { Temperature, } \\
{ }^{\circ} \mathrm{C}\end{array}$ \\
\hline PCU-H-002 & 53.1 & 1055 & 58.8 & 1088 & +5.7 & 33 \\
-003 & 53.9 & 1034 & 61.0 & 1065 & +7.1 & 31 \\
-006 & 54.1 & 1091 & 54.3 & 1090 & +0.2 & -1 \\
-007 & 55.0 & 1068 & 54.9 & 1080 & -0.1 & +12 \\
\hline \hline
\end{tabular}


Table 6 Heater "Burn-In" Data

\begin{tabular}{|c|c|c|c|c|}
\hline $\begin{array}{l}\text { Device } \\
\text { Tested }\end{array}$ & Label & Total "Burn-In" Cycles & $\begin{array}{l}\text { Input Power } \\
\text { Change, W }\end{array}$ & $\begin{array}{l}\text { Cathode Tempera- } \\
\text { ture Change, }{ }^{\circ} \mathrm{C}\end{array}$ \\
\hline Heater & PCU-H-001 & 90 & +1.0 & +15 \\
\hline$"$ & -002 & 140 & +1.4 & +14 \\
\hline$"$ & -003 & 140 & +1.3 & +26 \\
\hline$"$ & -005 & 40 & +0.9 & +40 \\
\hline$"$ & -006 & 20 & -0.4 & -8 \\
\hline$"$ & -007 & 50 & +0.7 & +20 \\
\hline$"$ & -008 & 110 & +0.2 & +3 \\
\hline$"$ & -009 & 70 & +1.4 & -5 \\
\hline Plasma Contactor & HCA-002 & 20 & +0.5 & - \\
\hline$"$ & -006 & 10 & +2.1 & - \\
\hline $\begin{array}{c}\text { Ion Thruster } \\
\text { Discharge Cathode }\end{array}$ & CAT-1 & 10 & +0.7 & - \\
\hline
\end{tabular}




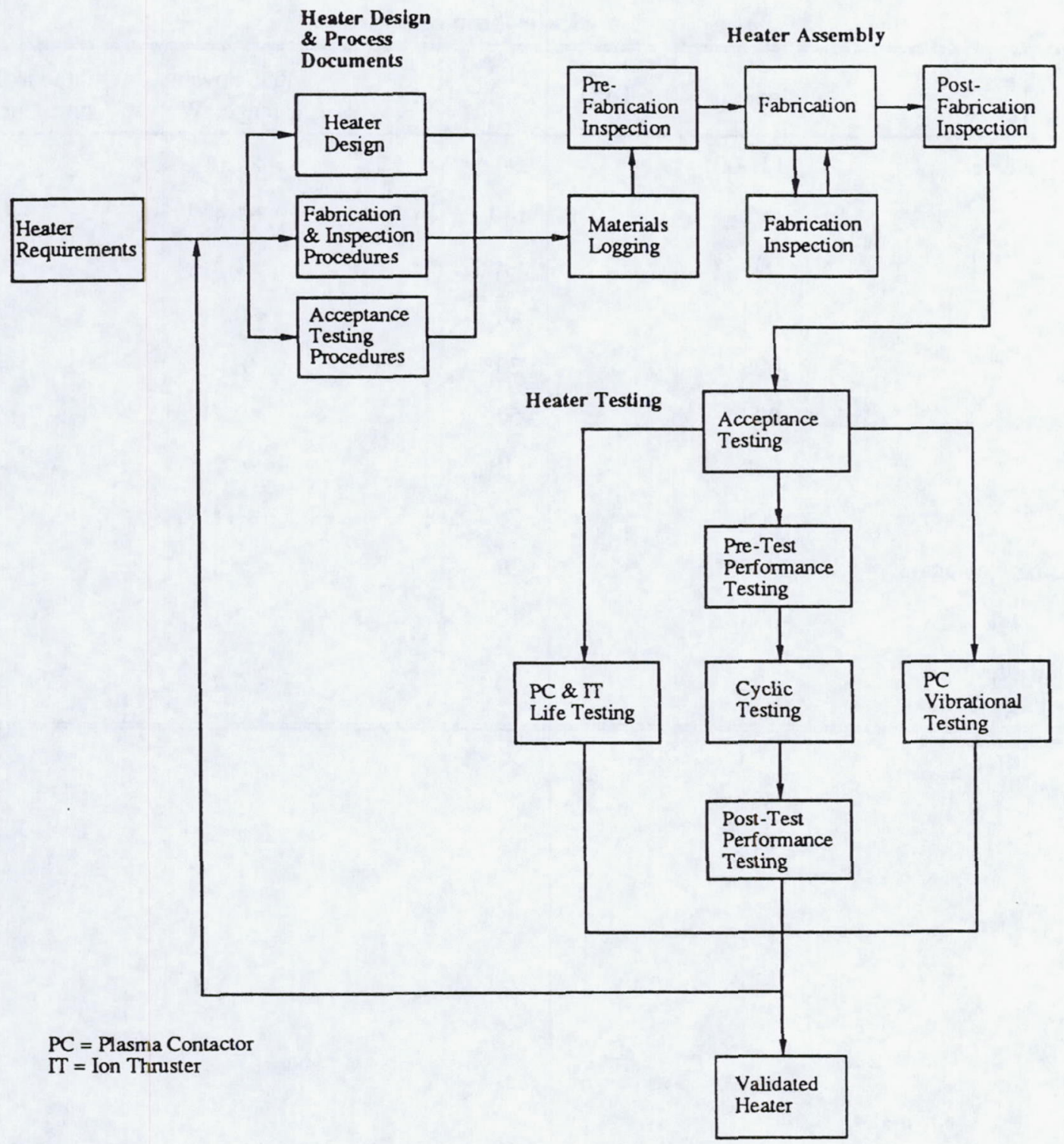

Fig. 1 Hollow cathode heater development flow chart. 


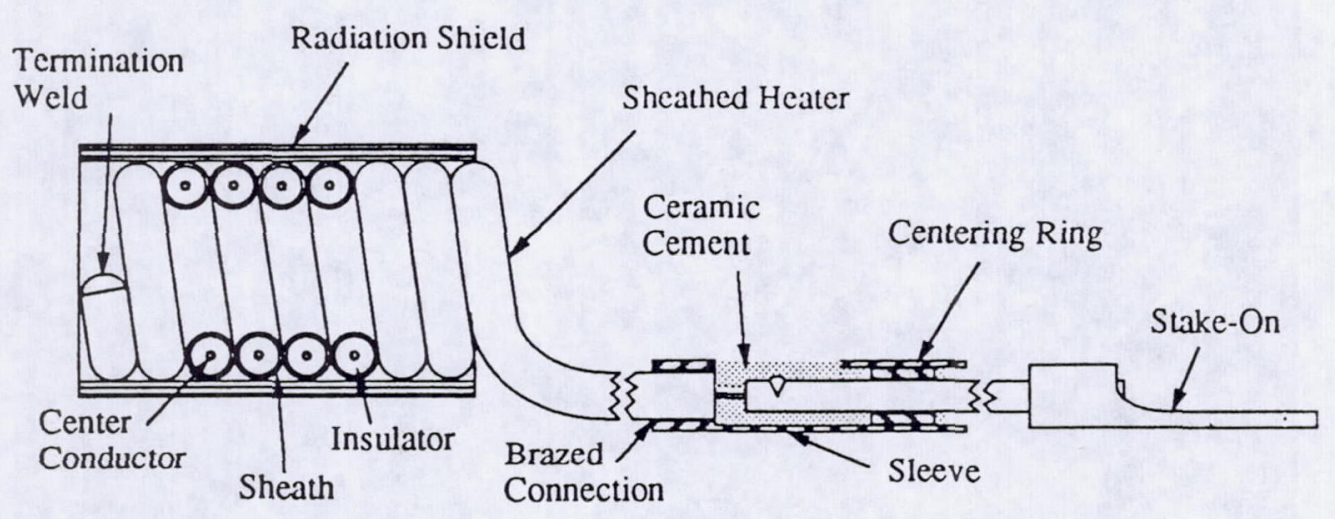

Fig. 2 Modified heater design.

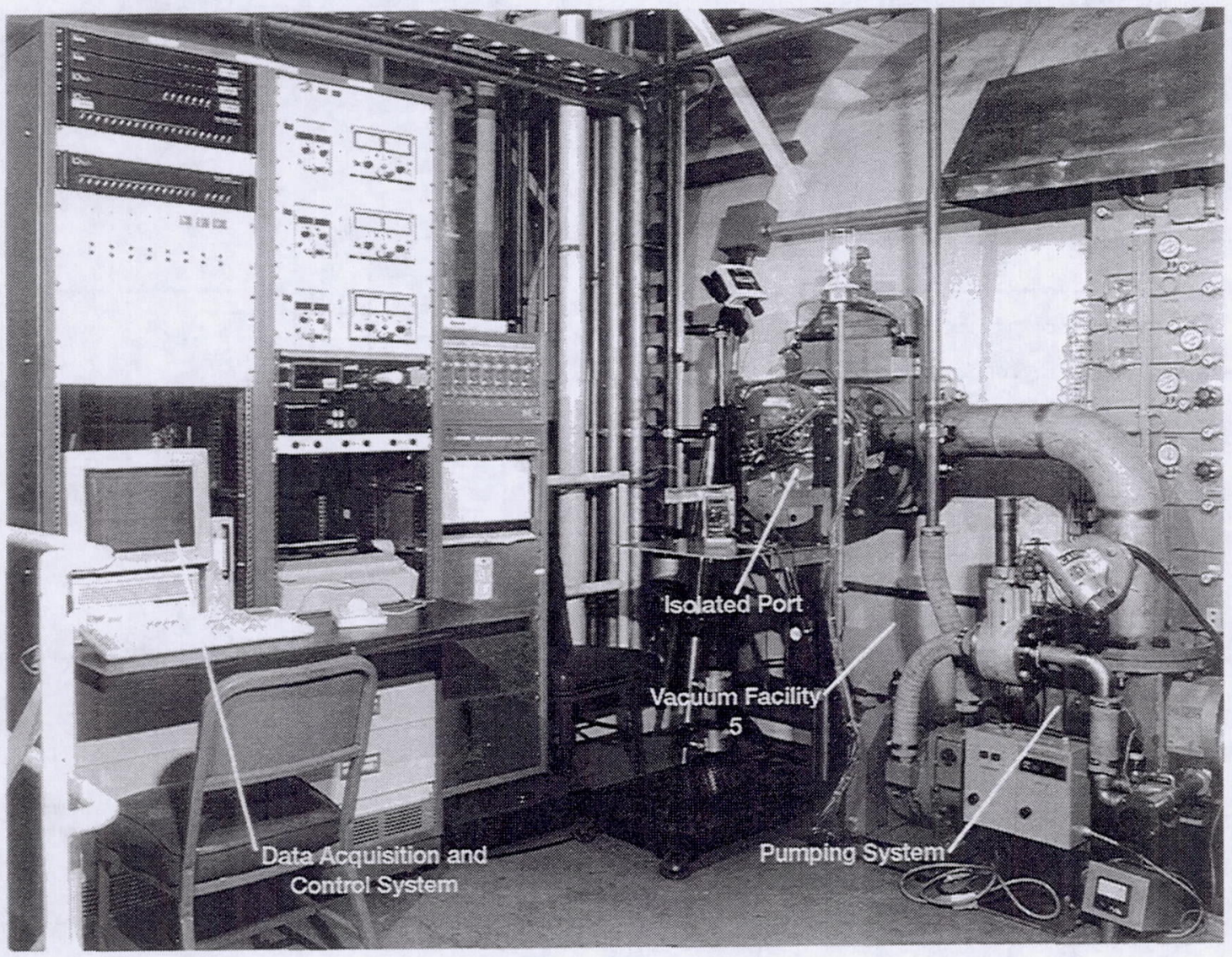

Fig. 3 Heater test facility. 


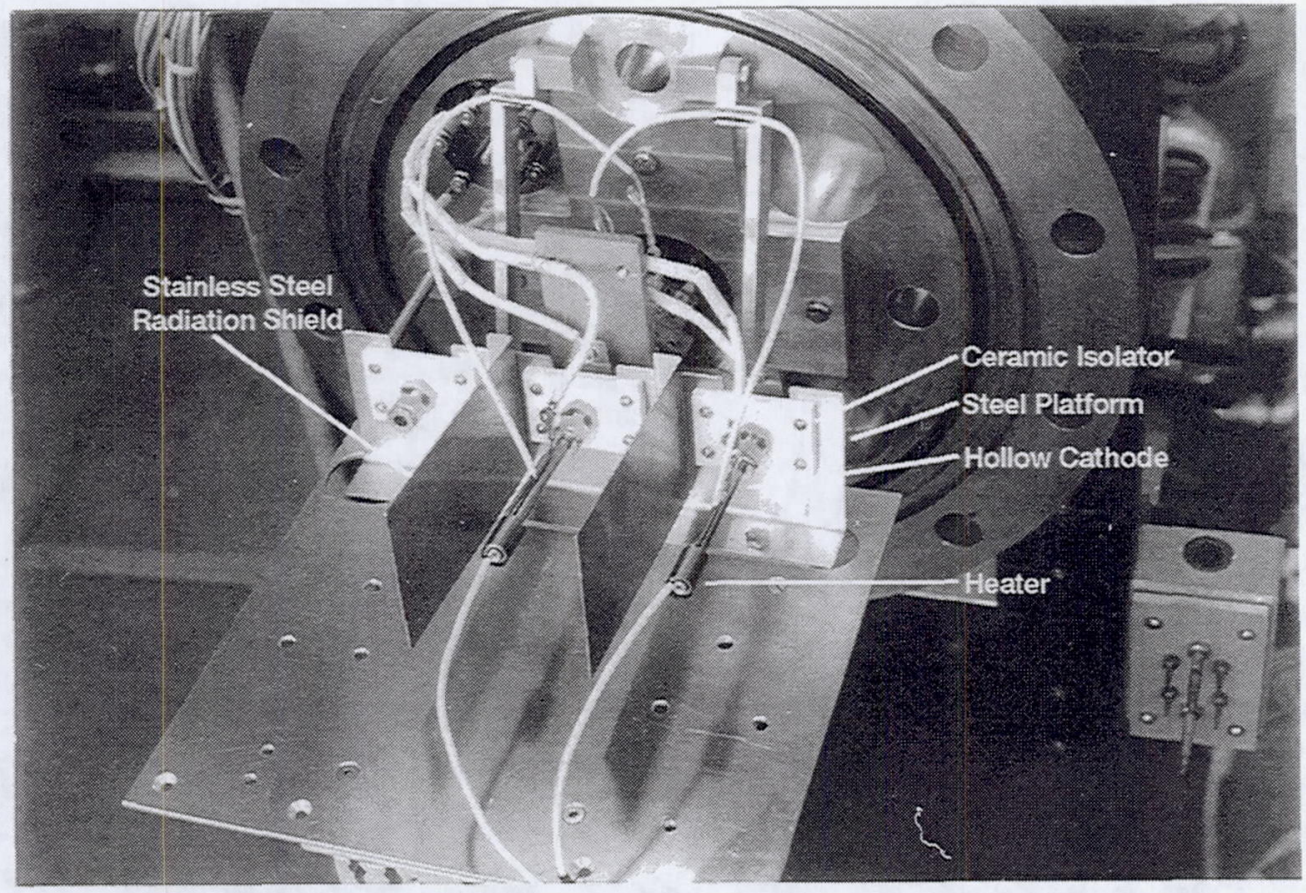

Fig. 4 Heater test platform with radiation shields.

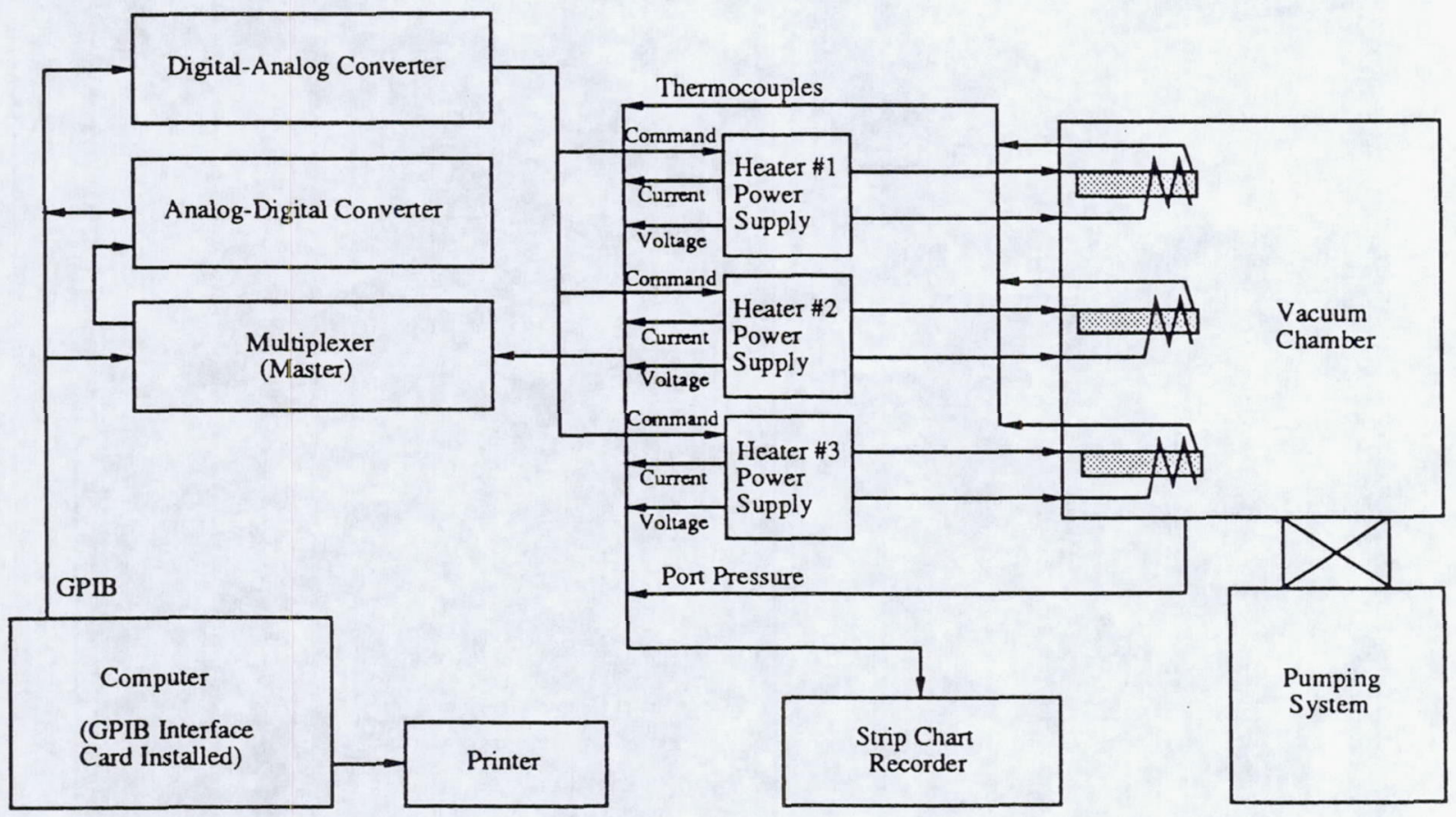

Fig. 5 Data acquisition and control system schematic. 


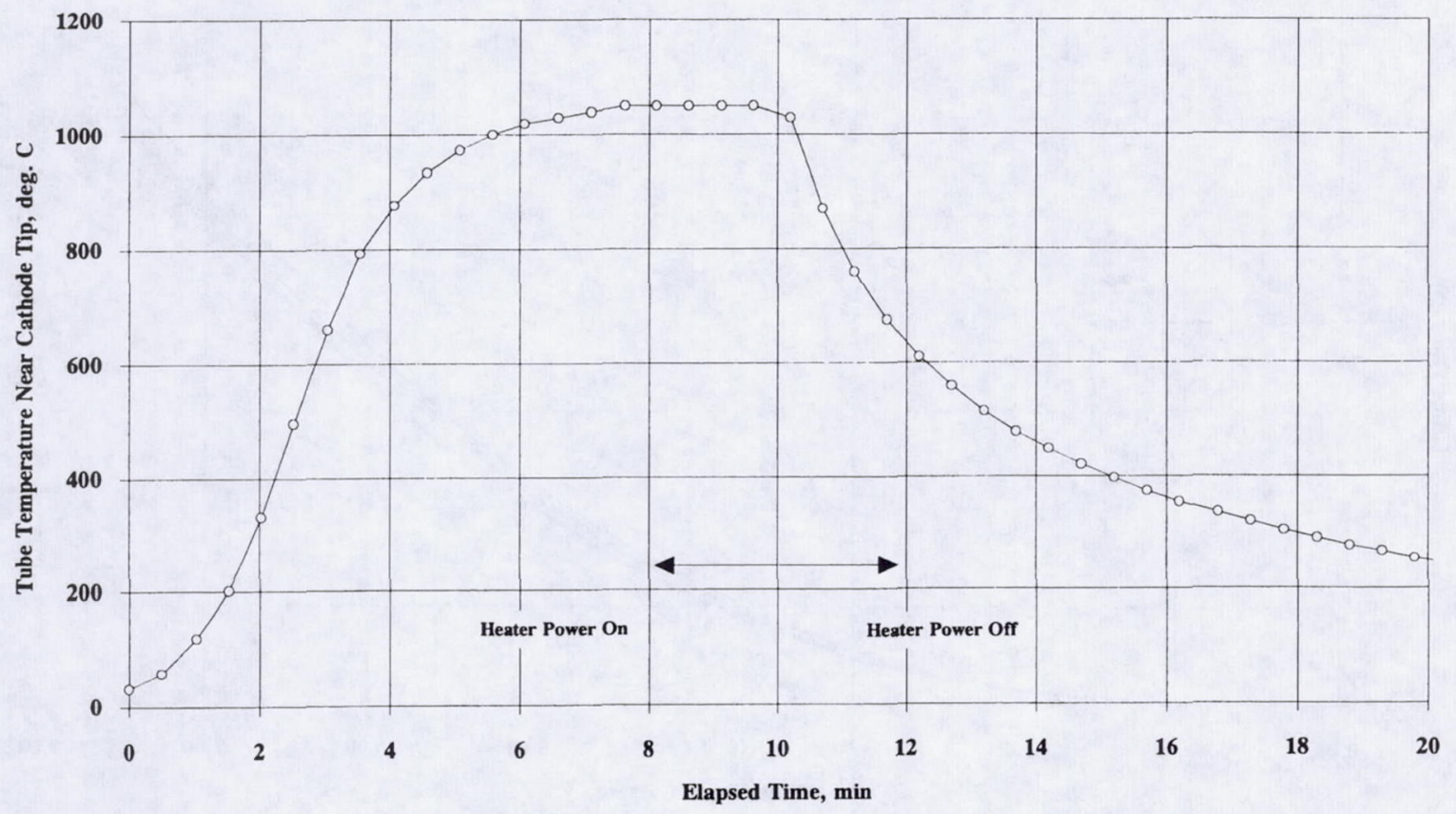

Fig. 6 Typical temperature profile for one cycle.

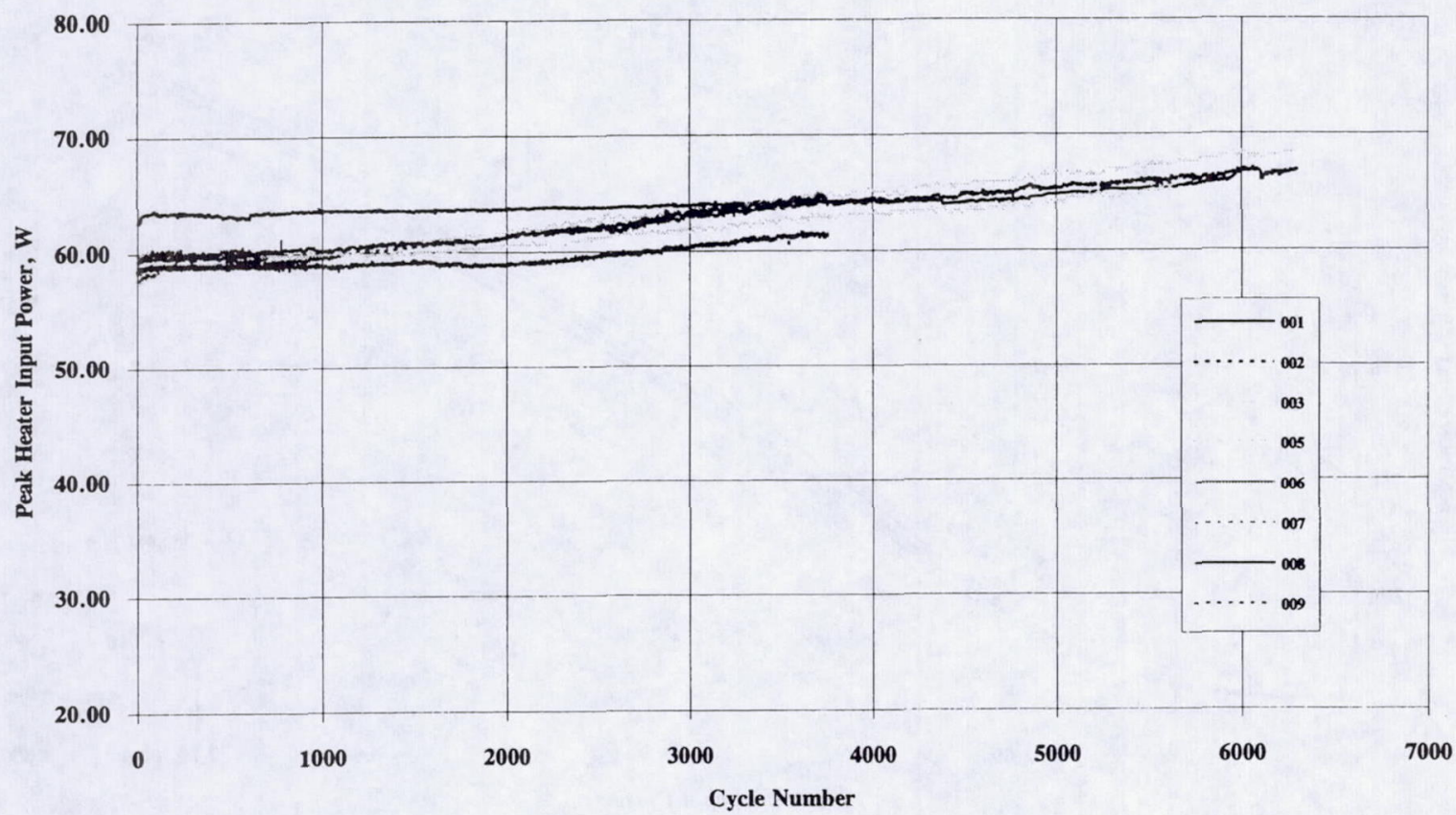

Fig. 7 Peak heater input powers throughout cyclic testing for all heaters. 


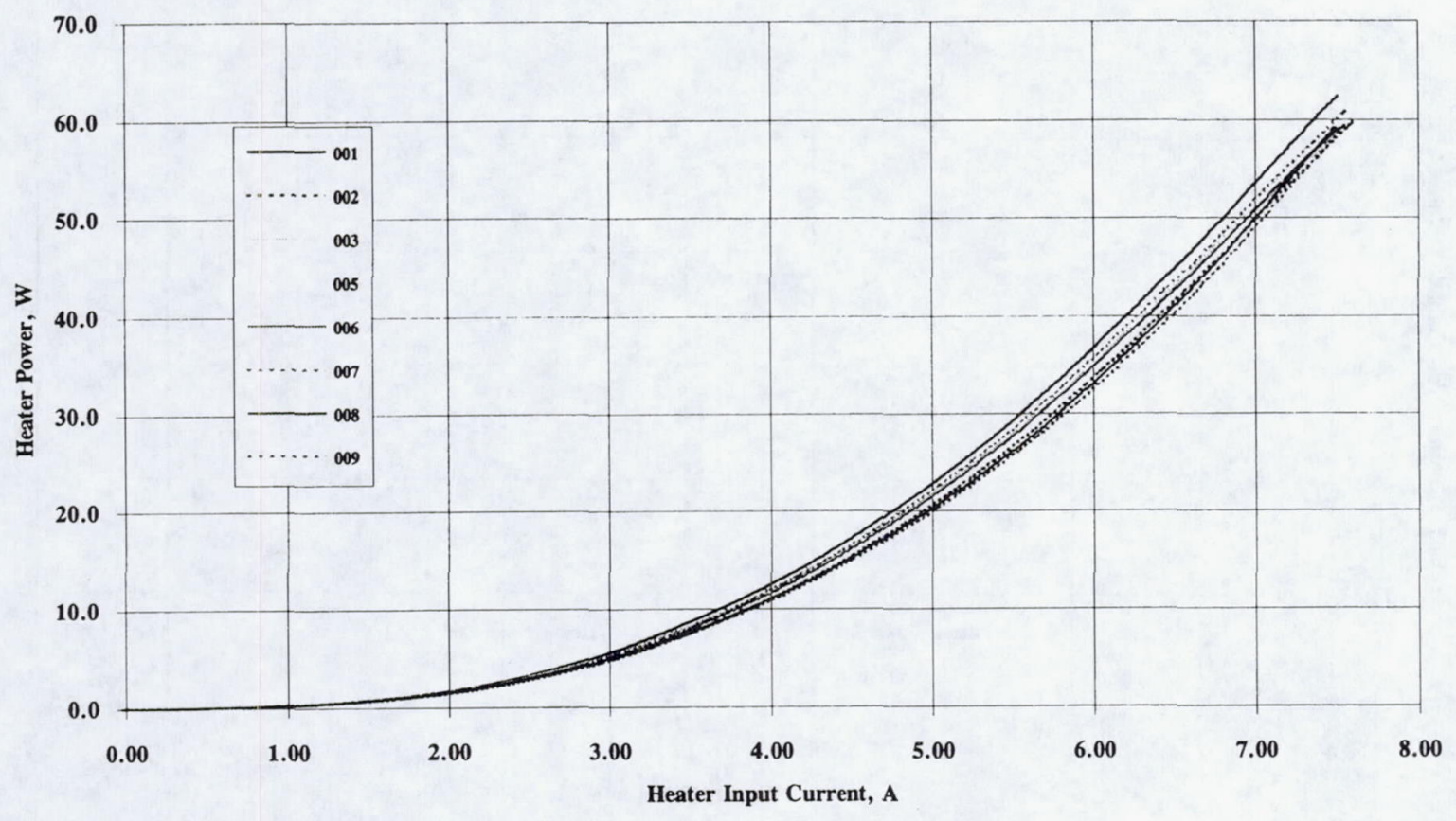

Fig. 8 Heater power as a function of input current.

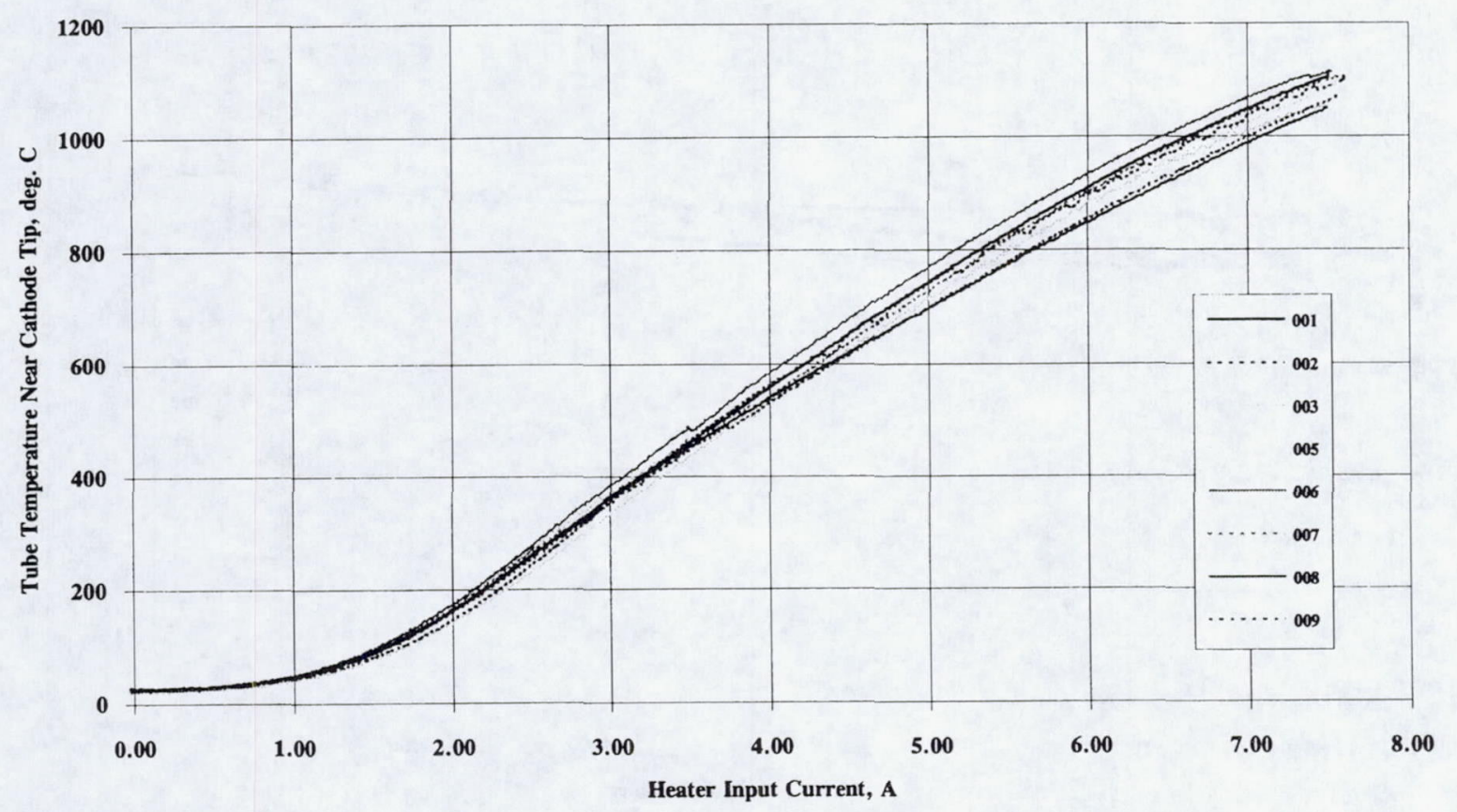

Fig. 9 Tube temperature near the cathode tip as a function of input current. 


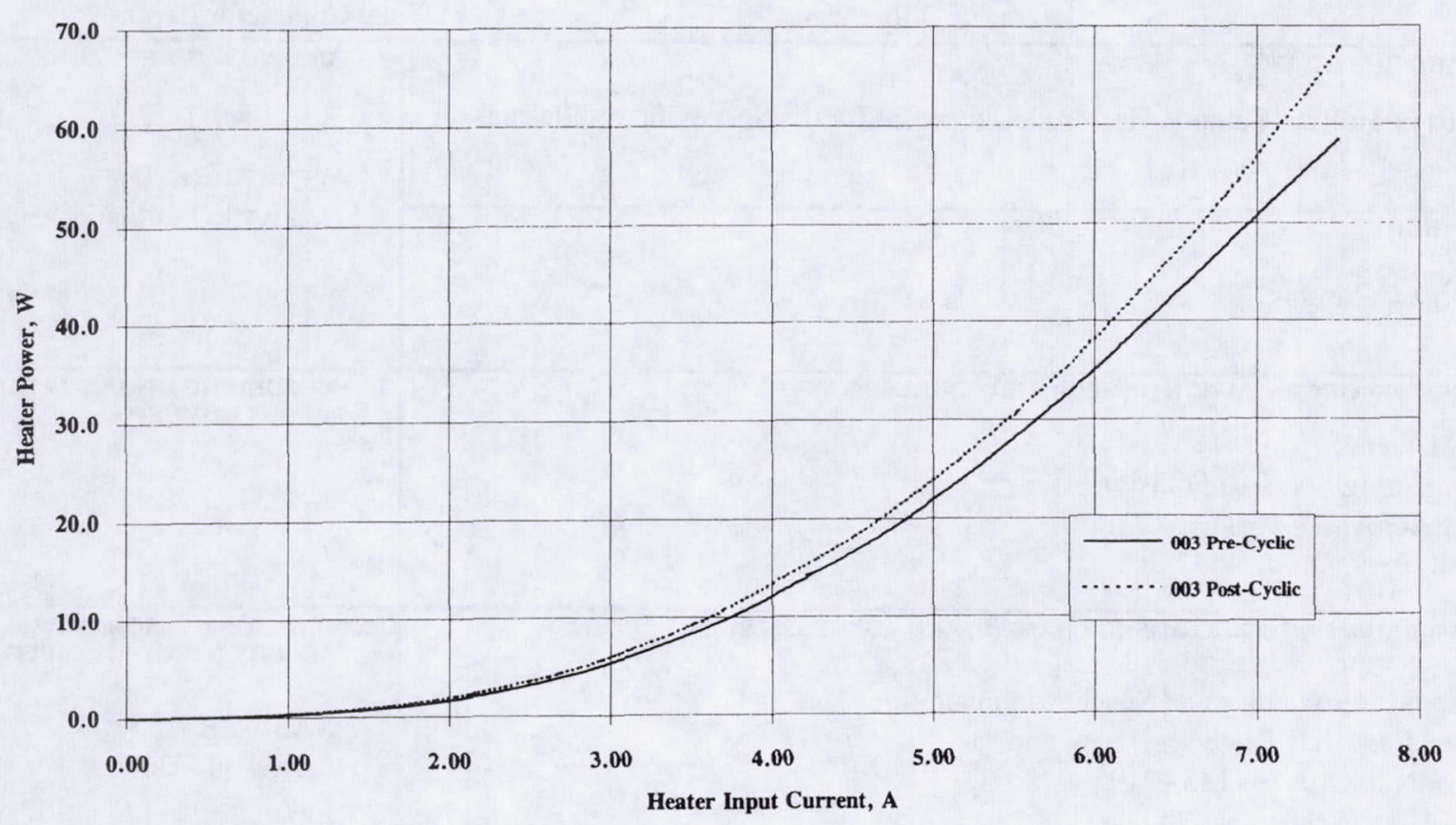

Fig. 10 Pre- and post-cyclic heater power as a function of input current for heater PCU-H-003.

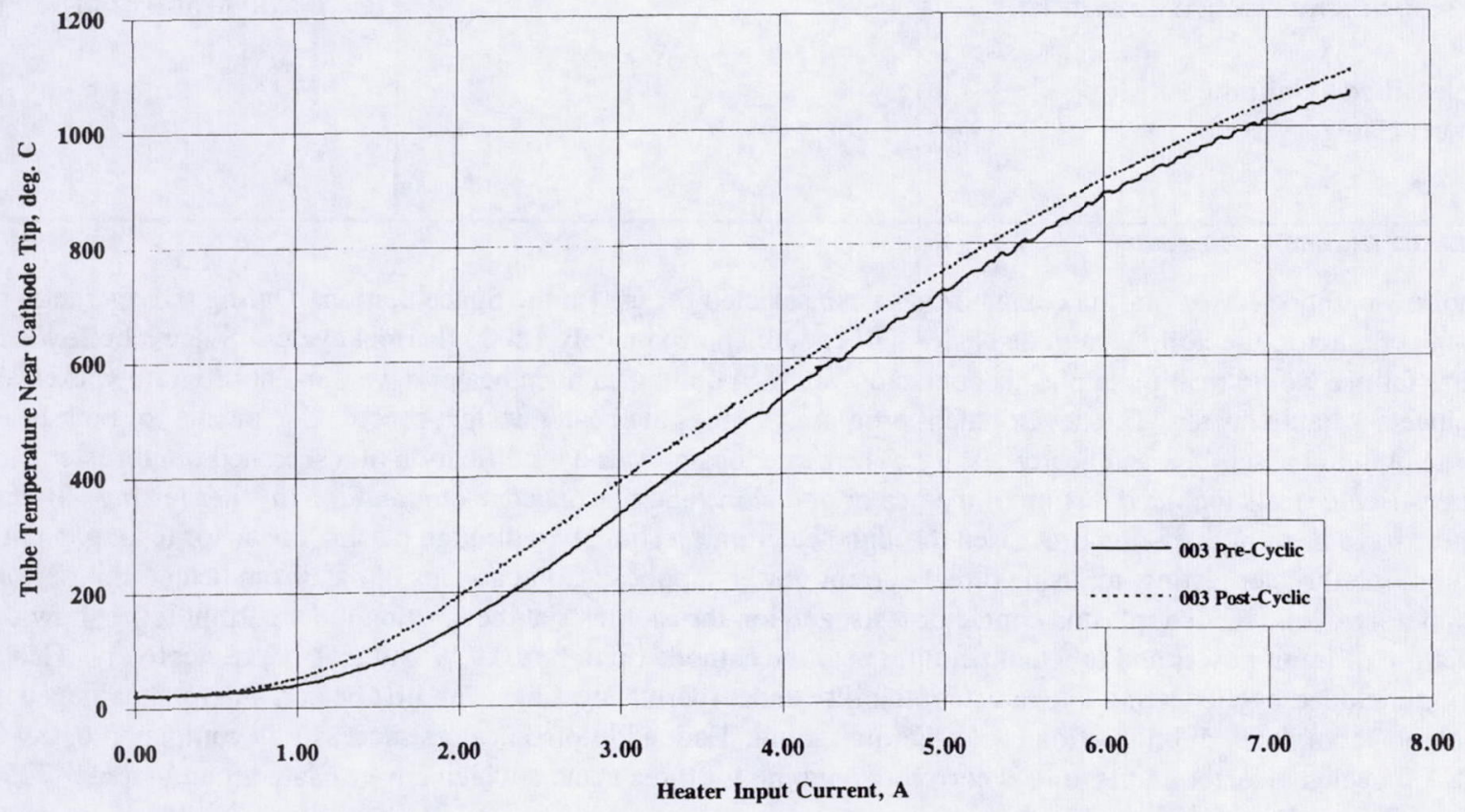

Fig. 11 Pre- and post-cyclic tube temperature near the cathode tip as a function of input current for heater PCU-H-003. 
Public reporting burden for this collection of information is estimated to average 1 hour per response, including the time for reviewing instructions, searching existing data sources, gathering and maintaining the data needed, and completing and reviewing the collection of information. Send comments regarding this burden estimate or any other aspect of this collection of information, including suggestions for reducing this burden, to Washington Headquarters Services, Directorate for Information Operations and Reports, 1215 Jefferson Davis Highway, Suite 1204, Arlington, VA 22202-4302, and to the Office of Management and Budget, Paperwork Reduction Project (0704-0188), Washington, DC 20503.

\begin{tabular}{|l|c|c|}
\hline 1. AGENCY USE ONLY (Leave blank) & $\begin{array}{c}\text { 2. REPORT DATE } \\
\text { July } 1994\end{array}$ & $\begin{array}{r}\text { 3. REPORT TYPE AND DATES COVERED } \\
\text { Final Contractor Report }\end{array}$
\end{tabular}

4. TITLE AND SUBTITLE

5. FUNDING NUMBERS

Status of Hollow Cathode Heater Development for the Space Station Plasma Contactor

WU-474-46-10

6. $A U T H O R(S)$

C-NAS3-25266

George C. Soulas

7. PERFORMING ORGANIZATION NAME(S) AND ADDRESS(ES)

NYMA, Inc.

Engineering Services Division

2001 Aerospace Parkway

Brook Park, Ohio 44142

9. SPONSORING/MONITORING AGENCY NAME(S) AND ADDRESS(ES)

National Aeronautics and Space Administration

Lewis Research Center

Cleveland, Ohio 44135-3191

8. PERFORMING ORGANIZATION

REPORT NUMBER

E-9030

11. SUPPLEMENTARY NOTES

Prepared for the 30th Joint Propulsion Conference cosponsored by AIAA, ASME, SAE, and ASEE, Indianapolis, Indiana, June 27-29, 1994. Project Manager, Michael J. Patterson, Space Propulsion Technology Division, NASA Lewis Research Center, organization code 5330, (216) 433-7481.

12a. DISTRIBUTION/AVAILABILITY STATEMENT 12b. DISTRIBUTION CODE

Unclassified - Unlimited

Subject Category 20

13. ABSTRACT (Maximum 200 words)

A hollow cathode-based plasma contactor has been selected for use on the Space Station. During the operation of the plasma contactor, the hollow cathode heater will endure approximately 12000 thermal cycles. Since a hollow cathode heater failure would result in a plasma contactor failure, a hollow cathode heater development program was established to produce a reliable heater. The development program includes the heater design, process documents for both heater fabrication and assembly, and heater testing. The heater design was a modification of a sheathed ion thruster cathode heater. Heater tests included testing of the heater unit alone and plasma contactor and ion thruster testing. To date, eight heaters have been or are being processed through heater unit testing, two through plasma contactor testing, and three through ion thruster testing, all using direct current power supplies. Comparisons of data from heater unit performance tests before cyclic testing, plasma contactor tests, and ion thruster tests at the ignition input current level show the average deviation of input power and tube temperature near the cathode tip to be $\pm 0.9 \mathrm{~W}$ and $\pm 21^{\circ} \mathrm{C}$, respectively. Heater unit testing included cyclic testing to evaluate reliability under thermal cycling. The first heater, although damaged during assembly, completed 5985 ignition cycles before failing. Four additional heaters successfully completed $6300,6300,700$, and 700 cycles. Heater unit testing is currently ongoing for three heaters which have to date accumulated $>7250,>5500$, and $>5500$ cycles.

\section{SUBJECT TERMS}

Heater; Hollow cathode; Plasma contactor; Ion thruster

\begin{tabular}{|c|c|}
\hline \multirow{2}{*}{$\begin{array}{c}\text { 19. SECURITY CLASSIFICATION } \\
\text { OF ABSTRACT } \\
\text { Unclassified }\end{array}$} & $\begin{array}{c}\text { 15. NUMBER OF PAGES } \\
17\end{array}$ \\
\cline { 2 - 3 } & $\begin{array}{c}\text { 16. PRICE CODE } \\
\text { A03 }\end{array}$ \\
\hline
\end{tabular}

\begin{tabular}{l|c} 
17. SECURITY CLASSIFICATION \\
$\begin{array}{c}\text { OF REPORT } \\
\text { Unclassified }\end{array}$ & $\begin{array}{c}\text { 18. SECURITY CLASSIFICATION } \\
\text { OF THIS PAGE } \\
\text { Unclassified }\end{array}$
\end{tabular}

